\title{
Psoriasis: familial predisposition and environmental factors
}

\author{
GUNNAR KAVLI， OLAV HELGE FØRDE， EGIL ARNESEN， SVEIN ERIK STENVOLD
}

\begin{abstract}
In a survey for coronary risk factors 14667 adult men and women answered a questionnaire on lifestyle, diet, and health, including whether they had psoriasis. The overall prevalence of psoriasis was $4.79 \%$ in men and $4.85 \%$ in women. The data showed an increasing incidence of psoriasis. The association with family history, lifestyle, diet, and health was explored by multiple regression analysis. The occurrence of psoriasis in first degree relatives contributed to more than $90 \%$ of the explained variance for both sexes. Of the other variables, only the positive association with rheumatoid arthritis was significant in both sexes.

It is concluded that the examined environmental factors have only minor effects on the prevalence of psoriasis.
\end{abstract}

\section{Introduction}

A genetic predisposition for psoriasis has been established, ${ }^{1-3}$ and climate, infection, diet, and stress have been suggested as provoking factors. ${ }^{12}$ No clear association with environment, however, has been shown.

\section{Subjects and methods}

In the district of Tromsø in 1979-80, 21329 adult men and women were invited to attend a screening for coronary risk factors; 16621 attended. Of these, 14667 answered a questionnaire on diet, health (including the presence of psoriasis), and lifestyle. Details are given elsewhere. ${ }^{4}$

All subjects were asked whether they had ever suffered from psoriasis and whether any of their relatives (mother, father, sister, brother) had. The occurrence of psoriasis in the family was graded from 0 to 4 , according to the number of positive answers.

The trends with age were tested by simple linear regression. The association with other variables was explored for each sex separately by standard multiple regression analysis. ${ }^{5}$ The following variables were used in the regression model: age, measurements of serum lipid and blood glucose concentrations, diastolic blood pressure, and body mass index; answers (which were graded) on the questionnaire to questions about consumption of coffee, milk, fruit and vegetables, minced meat, fish as a main dish, and analgesics and about frequency of intoxication from alcohol, physical activity at work and leisure, years of education, mental depression, problems of coping, and the occurrence of psoriasis and rheumatoid arthritis among first degree relatives; and answers of "yes" or "no" to questions about joint pain, rheumatoid arthritis, disturbances of sleep, and Lappish or Finnish ethnic origin. Only the significant $(\mathbf{p}<0.05)$ variables in either sex are presented from the multiple regression analysis that used all relevant variables.

\footnotetext{
Department of Dermatology and Institute of Community Medicine, University of Tromsø, Norway

GUNNAR KAVLI, MD, senior lecturer in dermatology

OLAV HELGE FØRDE, MD, senior lecturer, Institute of Community Medicine

EGIL ARNESEN, MD, senior lecturer, Institute of Community Medicine

SVEIN ERIK STENVOLD, MD, senior consultant in dermatology

Correspondence to: Dr Gunnar Kavli.
}

\section{Results}

Table I shows the prevalence of psoriasis according to age and sex. The overall prevalence was $4 \cdot 79 \%$ and $4 \cdot 85 \%$ in men and women, respectively. In women the prevalence decreased with increasing age $(\mathrm{p}<0.01)$, whereas no such trend was observed among men.

TABLE I-Prevalence of reported psoriasis according to age and sex

\begin{tabular}{ccc}
\hline Age $($ years $)$ & No $(\%)$ of men & No $(\%)$ of women \\
\hline $20-24$ & $837(3 \cdot 94)$ & $1223(5 \cdot 31)$ \\
$25-29$ & $1280(4 \cdot 92)$ & $1528(5 \cdot 76)$ \\
$30-34$ & $1494(4 \cdot 82)$ & $1586(4 \cdot 98)$ \\
$35-39$ & $1237(5 \cdot 25)$ & $1206(4 \cdot 48)$ \\
$40-44$ & $881(4 \cdot 99)$ & $875(4 \cdot 22)$ \\
$45-49$ & $797(4 \cdot 51)$ & $750(3 \cdot 33)$ \\
$50-54$ & $788(4 \cdot 70)$ & \\
\hline Total & $7314(4 \cdot 79)$ & $7168(4 \cdot 85)$ \\
\hline
\end{tabular}

Table II shows the $t$ values for the coefficients of the eight variables that were included in the final regression model. The occurrence of psoriasis among first degree relatives and rheumatoid arthritis were the only significant variables in both sexes. The occurrence in the family contributed more than $90 \%$ of the explained variance.

TABLE II-T values of regression coefficients in regression analysis

\begin{tabular}{lcc}
\hline \multicolumn{1}{c}{ Independent variables (and how graded) } & Men $(\mathbf{n}=7214)$ & Women $(\mathbf{n}=7016)$ \\
\hline Psoriasis among first degree relatives (0-4) & 23.09 & 23.08 \\
Rheumatoid arthritis (no/yes) & 2.80 & 2.72 \\
Joint pain (no/yes) & 3.26 & 1.31 \\
Consumption of coffee (cups/day) & 2.66 & 1.20 \\
Physical activity at work (1-4) & -1.91 & -2.45 \\
Intake of fruit and vegetables(1-4) & -2.28 & -0.21 \\
Smoking of cigarettes (no/yes) & 2.58 & 0.32 \\
Consumption of cigarettes (cigarettes/day) & -2.29 & 0.86 \\
Multiple R square & 0.077 & 0.074
\end{tabular}

Table III shows the prevalence of reported psoriasis related to the variables used in the regression analysis. The highest prevalences were observed in subjects with psoriasis in the family; they were more than 12 times higher among subjects with at least two diseased relatives than among those without. Subjects with rheumatoid arthritis and joint pain also had a higher risk of psoriasis than those without. Two dietary variables were significantly associated with psoriasis in men only: coffee drinking was positively associated and intake of fruit and vegetables negatively associated with psoriasis. In women a negative association between psoriasis and physical activity at work was observed. In men smoking of cigarettes was peculiarly associated with an increased prevalence of psoriasis compared with non-smokers but with a decreased prevalence of psoriasis with increased consumption of cigarettes.

\section{Discussion}

The "lifetime" prevalence of psoriasis in this population was higher than that in similar studies from Denmark ${ }^{6}$ and the Faröe Islands. ${ }^{1}$ The figures from the Faröe Islands, however, were based on the prevalence of psoriasis at a screening examination, whereas the Danish study posed a question identical with ours in an interview. Despite methodological disparities the overall prevalence we found seems to be quite high. 
TABLE III-Prevalence (\%) of reported psoriasis for selected variables

\begin{tabular}{|c|c|c|}
\hline Variables & No $(\%)$ of men & No (\%) of women \\
\hline $\begin{array}{l}\text { No of first degree relatives with psoriasis }{ }^{\star} \text { : } \\
0 \\
1 \\
2 \\
3\end{array}$ & $\begin{array}{r}6774(3 \cdot 28) \\
462(20 \cdot 78) \\
71(42 \cdot 25) \\
7(28 \cdot 57)\end{array}$ & $\begin{array}{r}6523(3.33) \\
529(15 \cdot 31) \\
104(40 \cdot 38) \\
13(61 \cdot 54)\end{array}$ \\
\hline $\begin{array}{l}\text { Rheumatoid arthritis: } \\
\text { No } \\
\text { Yes }\end{array}$ & $\begin{array}{r}7150(4 \cdot 63) \\
111(13 \cdot 51)\end{array}$ & $\begin{array}{r}6964(4 \cdot 57) \\
111(11 \cdot 71)\end{array}$ \\
\hline $\begin{array}{l}\text { Joint pain: } \\
\text { No } \\
\text { Yes }\end{array}$ & $\begin{array}{rr}6321 & (4.33) \\
993 & (8.56)\end{array}$ & $\begin{array}{r}6216(4 \cdot 62) \\
953(6 \cdot 40)\end{array}$ \\
\hline $\begin{array}{l}\text { Consumption of coffee (cups/day): } \\
<1 \\
1-4 \\
5-8 \\
9+\end{array}$ & $\begin{array}{rr}505 & (3 \cdot 17) \\
2368 & (4 \cdot 05) \\
3255 & (4 \cdot 98) \\
1163 & (6 \cdot 53)\end{array}$ & $\begin{array}{rr}556 & (5 \cdot 58) \\
3043 & (3 \cdot 94) \\
2858 & (5 \cdot 25) \\
682 & (6 \cdot 01)\end{array}$ \\
\hline $\begin{array}{l}\text { Physical activity at work: } \\
\text { Sedentary } \\
\text { Moderate } \\
\text { Intermediate } \\
\text { Heavy }\end{array}$ & $\begin{array}{r}3028(4.95) \\
1816(4 \cdot 85) \\
1617(4 \cdot 82) \\
843(4 \cdot 03)\end{array}$ & $\begin{array}{rr}2113 & (5 \cdot 54) \\
3829 & (4 \cdot 81) \\
1127 & (3 \cdot 64) \\
78 & (3 \cdot 85)\end{array}$ \\
\hline $\begin{array}{l}\text { Intake of fruit and vegetables: } \\
\leq \text { Twice a month } \\
\text { Once a week } \\
\text { Two to three times a week } \\
\text { Daily }\end{array}$ & $\begin{array}{rr}629(6 \cdot 36) \\
1223 \\
2308(5 \cdot 72) \\
3140(4 \cdot 08)\end{array}$ & $\begin{array}{rr}157(7 \cdot 64) \\
559(4 \cdot 29) \\
1761(4 \cdot 60) \\
4686(4 \cdot 91)\end{array}$ \\
\hline $\begin{array}{l}\text { Cigarettes/day: } \\
0 \\
1-9 \\
10-19 \\
20+\end{array}$ & $\begin{aligned} 3870 & (4 \cdot 26) \\
575 & (6 \cdot 09) \\
1866 & (5 \cdot 25) \\
1002 & (5 \cdot 19)\end{aligned}$ & $\begin{array}{rr}3859 & (4 \cdot 33) \\
1045 & (5 \cdot 26) \\
1872 & (5 \cdot 61) \\
390 & (5 \cdot 38)\end{array}$ \\
\hline Total & $7314(4 \cdot 79)$ & $7169(4 \cdot 85)$ \\
\hline
\end{tabular}

*Units are mother, father, brothers, and sisters.

Hellgren found a higher prevalence of psoriasis with greater age, ${ }^{7}$ and Farber and Nall also observed an increased prevalence with age in women, ${ }^{2}$ whereas Brandrup et al found no consistent association. ${ }^{6}$ Psoriasis is a chronic disease that does not influence the expectation of life, and onset may occur at any age. ${ }^{7}$ With constant incidence we therefore expected an increased prevalence with age. A lower threshold of seeking medical attention and a higher diagnostic "intensity" in younger subjects can not be ruled out. The decreasing lifetime prevalence in women and the lack of an increase in men may, however, also suggest a cohort effect with increased incidence, indicating the influence of environmental factors.

Only occurrence of psoriasis in the family emerged with a strong and consistent increased risk. Although subjects with psoriasis are $\underline{\underline{T}}$ more likely to be aware of psoriasis among first degree relatives, the 3 strength of the association was greater than expected from this bias. $\stackrel{\unrhd}{\unrhd}$ Rheumatoid arthritis is probably also truly associated with $C$ psoriasis. The association with consumption of coffee was $\widehat{\widehat{O}}$ unexpected. Coffee increases lipolysis,${ }^{8}$ however, making free arachidonic acid available for the leucotriene $B_{4}$ pathway. This ${ }_{\mathbb{D}}^{D}$ system is important in the pathogenesis of psoriasis. ${ }^{9}$ The inverse ${ }^{\infty}$ relation with intake of fruit and vegetables supports Vorhees's suggestion that increased intake of vegetable oils may block the transformation of free arachidonic acid to leucotriene $\mathrm{B}_{4}{ }^{9}$

The number of variables tested, however, suggests a need for caution. The most striking result was the lack of consistent association in both sexes with variables of lifestyle. Neither the variables of diet nor those of mental stress showed a role consistent $\overparen{\AA}$ with causal or provoking factors in the pathogenesis of psoriasis. Occurrence in the family, however, does not exclude environmental ${ }^{\text {s }}$ factors acting within families. So far psoriasis must be considered to $\vec{\circ}$ be a predominantly genetic disease.

This study was carried out in cooperation with the National Mass Radiography Service, Oslo, Norway.

\section{References}

1 Lomholt G. Psoriasis, spontaneous course and genetics: a census study on the prevalence of skin disease in the Faroe Islands. Copenhagen: G E C Gad, 1963.

2 Farber E, Nall ML. The natural history of psoriasis in 5600 patients. Dermatologica 1974;148:1-18. 3 Brandrup F, Hauge M, Henningsen K, Eriksen B. Psoriasis in an unselected series of twins. Arch $\mathrm{O}$

Dermatol 1978;114:874-8.
4 Thelle DS, Arnesen E, Førde OH. The Tromsø heart study: does coffee raise serum cholesterol? $\vec{N}$ N Engl f Med 1983;303:1454-7.

5 Nie HH. Statistical package for the social sciences. 2nd ed. New York: McGraw Hill, 1975.
6 Brandrup F, Green A, Holm N. Praevalensen af psoriasis i Danmark. Ugeskr Laeger 1982;144: $\frac{O}{\widetilde{O}}$ 3538-41.

7 Hellgren L. Psoriasis. The prevalence in sex, age and occupational groups in total populations in Sweden. Morphology, inheritance and association with other skin and rheumatic diseases. Stockholm: Almkvist and Wiksell, 1967

8 Avogaro $P$, Capri C, Pais M, Cazzolato G. Plasma and urine cortisol behaviour and fat mobilisation of in man after coffee ingestion. Isr f Med Sci 1973;9:114-9.

9 Vorhees JJ. Leukotrienes and other lipoxygenase products in the pathogenesis and therapy of psoriasis and other dermatoses. Arch Dermatol 1983;119:541-7.

(Accepted 17 July 1985)

\section{YEARS AGO}

In my last letter, I referred to some proposed changes in the constitution of the "Conseil Sanitaire," about which there had been difficulty between Surgeon-Major Greene and the higher powers. The matter has been settled by the appointment of the Chief Pharmacien, Dr. Durri Bey, Lecturer on Surgery at the Medical School, and Mr. Crookshank, Director of Prisons. The latter is the only one of the three new members proposed by Mr. Greene, but the Council will gain in him as well as in Dr. Durri Bey a distinct accession of strength.

Dr. Durri Bey is a surgeon of considerable ability and energy. He recently removed from a man's bladder, by the suprapubic method, a calculus weighing 358 grammes (about 12 ounces). The patient now-three weeks after the operation-is convalescent, and the wound nearly closed. A year ago, there was no such thing as an out-patient known at the Kasr-el-Ein Hospital. There is now a daily attendance of out-patients averaging about 50 ; and further, they are utilised by Mr. Milton for clinical teaching to a class of about a dozen advanced students. This is an immense gain to the medical school. Dr. Cafrawy, who is an M.D. of Paris, has been appointed medical officer of the Ezbekieh quarter of Cairo. This post was previously held by Dr. Sidney Davies. Another Paris M.D., a Frenchman, was a candidate for the post. He had the highest recommendations, but, as there was a well qualified native in the field, which is not generally the case for these appointments, it was considered that he must have preference to a European. The only objection to Dr. Cafrawy was that he had been a supporter of Arabi, but this was rightly considered to be no longer any objection. Notwithstanding, it is a pity that the European candidate was not elected. Before the post was vacated by its English tenant, there was a daily attendance of about 40 poor natives treated as out-patients, chiefly surgical cases, frequently requiring operations. The French doctor would undoubt- edly have continued this work, but it is very unlikely that the native medical man, however well qualified, will do any more work than he is obliged to do. There has been an outbreak of small-pox among the black women and children who accompanied the Soudanese regiments lately returned from $\delta$ the Soudan. It seems that there has been no provision for vaccinating either the soldiers or their families. These people were scattered in different partso of Cairo, and were consequently a source of danger to the public health. It was wisely decided to establish a tent-hospital for them. This has been done, $N$ and is situated at Abbasieh, in the desert, about 200 yards east of the barracks. There are five tents, open on all sides, containing 44 patients, about three-fourths of whom are under 12 years of age. They are provided with a limited quantity of bedding, and large warm blankets, but no bedsteads. Only two adult men have been received. About 50 patients havew been received in all during three weeks, two only of whom have died. There? are now only two or three serious cases, the majority being convalescent 0 Several cases, however, were confluent. The small number of men affected is $\widetilde{\widetilde{D}}$

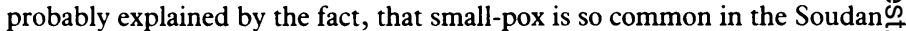
that few reach manhood without having caught it. The small mortality at the encampment is undoubtedly due chiefly to the unlimited supply of air. A native medical man remains at the encampment during the day, and acts under the direction of Mr. Milton. There are one or two European hospitals $\frac{?}{\mathbb{P}}$ in Cairo, the patients of which would be much benefited if they could change $\varrho$ places with the Soudanese in the encampment. A circular has been sent to the European medical men by their consuls, requesting them to notify infectious diseases. This is a step in the right direction, but the Europeano doctors, other than English, will probably object to it; and, as long as the capitulations exist, there will be no efficient notification. (British Medical fournal 1885;ii:121.) 